\title{
Reflections and collective production about being a municipal health counselor
}

\author{
Reflexões e produção coletiva sobre o "ser" conselheiro municipal de saúde \\ Reflexiones y producción colectiva sobre "ser" consejero municipal de salud
}

\begin{abstract}
Angela Maria Gomes', Liane Colliselli", Maria Elisabeth Kleba', Valéria Silvana Faganello Madureira"
' Universidade Comunitária da Região de Chapecó, Postgraduate Program in Social Policies and Regional Dynamics. Chapecó, Santa Catarina, Brazil.

"Universidade Federal da Fronteira Sul, Nursing Deparment. Chapecó, Santa Catarina, Brasil.
\end{abstract}

\begin{abstract}
How to cite this article:
Gomes AM, Colliselli L, Kleba ME, Madureira VSF. Reflections and collective production about being a municipal health counselor. Rev Bras Enferm [Internet]. 2018;71(Suppl 1):496-504. [Thematic Issue: Contributions and challenges of nursing practices in collective health] DOI: http://dx.doi.org/10.1590/0034-7167-2017-0369
\end{abstract}

Submission: 06-01-2017 Approval: 08-06-2017

\begin{abstract}
Objective: to identify the participation dynamics of a municipal council and to develop a critical-reflexive process on "being a counselor", identifying weaknesses and possibilities of this council, in addition to collectively generating new knowledge and (re) elaborating the MHC Ordinary Law. Method: Convergent care research, including documentary analysis, non-participant observation and thematic workshops. The research was carried out in 2016, with municipal health counselors from a city in the Western Region of Santa Catarina. Results: this study made it possible to identify forms of social participation that should be strengthened in the performance of social power, to reflect and share individual experiences, to anchor them in the current legislation, and to build knowledge that enabled the elaboration/organization of a product - a new text for the Ordinary Law of the Council, adjusted to current legislation. Final considerations: There is a need to increase participation, considering the presence of the counselors in the meetings, the effective representation and a greater interaction in the discussions and deliberations of the council.
\end{abstract}

Descriptors: Health Council; Social Participation; Public Policy; Nursing Education; Nursing Research.

\section{RESUMO}

Objetivo: Identificar a dinâmica participativa de um conselho municipal de saúde, com o desenvolvimento de processo críticoreflexivo sobre o "ser conselheiro", apontando fragilidades e possibilidades desse colegiado, além de gerar coletivamente novos saberes e a (re)elaboração da Lei Ordinária do CMS. Método: Pesquisa convergente assistencial, incluindo análise documental, observação não participante e oficinas temáticas. A pesquisa foi em 2016, com conselheiros municipais de saúde de um município da Região Oeste de Santa Catarina. Resultados: Este estudo possibilitou identificar formas de participação social a serem fortalecidas no exercício do controle social, compartilhar e refletir sobre as experiências individuais, ancorá-las na legislação vigente e construir conhecimentos que oportunizaram a elaboração/organização de um produto - readequação da Lei Ordinária do conselho à legislação vigente. Considerações finais: Pontua-se a necessidade de ampliar a participação, considerando a presença dos conselheiros nas reuniões, a representação efetiva e a sua maior interação nas discussões e deliberações do conselho.

Descritores: Conselhos de Saúde; Participação Social; Política Pública; Educação em Enfermagem; Pesquisa em Enfermagem.

\section{RESUMEN}

Objetivo: Identificar la dinámica participativa de un consejo municipal de salud mediante el desarrollo de un proceso críticoreflexivo sobre "ser consejero", señalando las fragilidades y posibilidades de este colegiado, además de generar, colectivamente, nuevos saberes y la (re)elaboración de la Ley Ordinaria del CMS. Método: se trata de una investigación convergente asistencial, incluyendo análisis documental, observación no participante y talleres temáticos. La investigación se llevó a cabo en 2016, con consejeros municipales de salud de un municipio de la Región Oeste de Santa Catarina. Resultados: este estudio permitió compartir y reflexionar acerca de experiencias individuales e identificó diversas formas de participación social que deberían fortalecerse en el ejercicio del control social al insertarlas en la legislación vigente con el intuito de construir conocimientos, 
lo que posibilitó la elaboración/organización de un producto - readecuación de la Ley Ordinaria del consejo a la legislación vigente. Consideraciones finales: se hace necesario ampliar la participación, considerando la presencia de los consejeros en las reuniones con una representación eficaz y una intervención más amplia en las discusiones y deliberaciones del consejo.

Descriptores: Consejos de Salud; Participación Social; Política Pública; Educación en Enfermería; Investigación en Enfermería.

\section{CORRESPONDING AUTHORＡngela Maria GomesＥ-mail: angela.gomes@unochapeco.edu.br}

\section{INTRODUCTION}

The creation of the Unified Health System $\left(S_{U} S^{*}\right)$, an important Brazilian public health policy, brings a new aspect to health governance: social participation becomes the principle of engagement of new political subjects in health-related decision-making(1). SUS represented the institutionalization of a democratic management of health policies and provided society with better opportunities to perform social power. This means society can understand, participate and inspect the actions of the State, and citizens can intervene in planning, implementation and evaluation of these actions ${ }^{(2)}$.

The Law No 8,142/90, which regulated Health Councils and Conferences on Health as SUS deliberative spaces, was a major achievement of social power. This Law defines the Health Councils as "permanent and deliberative collegiate bodies, with the function of formulating strategies and controlling and supervising the implementation of health policies, including economic and financial aspects"(3). As part of this deliberative character, the participants must recognize their role as counselors and know how to perform social power and participate in the construction of health management tools. For this reason, the dissemination of information about the legal framework of SUS and about the role of health counselors are essential actions for strengthening the SUS.

The current legislation regulates and guides the functioning of the Health Councils, determining, among various functions of the counselors, two of extreme relevance: the first refers to the responsibility of "elaborating legal instruments (legislation) and other operating rules", while the second determines the "definition of guidelines for the elaboration of health plans and deliberation on their content, according to the different epidemiological situations and the organizational capacity of services"(4).

The scenario of this study was the Municipal Health Council (MHC) created in September $1993^{(5)}$ and first articulated with the Federal University of Fronteira Sul (UFFS) in 2015. This year, as the result of the partnership between the two organizations, the outreach project "Permanent Education for Municipal Health Counselors: West Macro-region", approved in Notice No. 804/UFFS/2014, was implemented with the purpose of strengthening the Municipal Councils by providing qualification. At that time, the invitation was extended to the 27 cities of the Region, but the city under study did not join the process, for reasons that were not justified.

Nursing encourages the formation of critical and reflexive professionals, who are committed to their social role, as active subjects in the reality in which they are inserted and contribute to the construction of public policies based on SUS principles ${ }^{(6)}$. In addition, it is considered that "the nurse helps to transmit knowledge to the population about the functioning of SUS, as well as information about their rights and duties"(6).

\section{OBJECTIVE}

Based on the above and considering the need to broaden the knowledge on social power and improve social participation in health in this region, the present study aimed to identify the participation dynamics of a municipal council and to develop a critical-reflexive process on "being a counselor", identifying weaknesses and possibilities of this council, in addition to collectively generating new knowledge and (re) elaborating the MHC Ordinary Law.

\section{METHOD}

\section{Ethical aspects}

The data presented here are the result of an undergraduate thesis from the Federal University of Fronteira Sul (UFFS), submitted and approved by the Research Ethics Committee of the UFFS.

\section{Theoretical-methodological framework}

\section{Study type}

This is a qualitative research, using the methodological framework of Convergent-Care Research (CCR). The choice for this framework is based on the possibility of contributing to an adequate solution to the specific context, when identifying fragilities of an object/phenomenon of investigation during the insertion in the professional practice and the interaction between the researcher and the issues/problems ${ }^{(7)}$. For the construction and/or improvement of knowledge or care, a closer approximation, either with practice or with research, is necessary ${ }^{(8)}$. The researcher must be willing to be inserted in the reality of the research context along with the subjects throughout the process ${ }^{(8)}$.

\section{Methodological Procedures}

The CCR determines five phases in the research process: conception, instrumentation, investigation, analysis and interpretation ${ }^{(8)}$.

The conception phase is destined for aligning the theme of the study, the research questions and the theoretical framework on the subject ${ }^{(8)}$. In this study, the conception phase occurred during the process described in the introduction, with

* The acronym SUS stands for Sistema Único de Saúde in Portuguese and is widely known as SUS. 
a dialogue with municipal counselors already combining practical experiences with theoretical aspects, which resulted in the proposal of the present study. The instrumentation phase consists of outlining the methodological procedures of the research ${ }^{(8)}$, which are better described in the next items. In CCR, the investigation phase comprises the development of compatible and adequate data collection strategies derived from creativity of the researcher. The analysis phase requires the use of a variety of analytical methods and techniques, due to the complexity of this type of research ${ }^{(8)}$.

The last phase is interpretation, a process that intercalates moments of approximation, detachment and convergence ${ }^{(8)}$. In this study, after the implementation of each strategy and analysis of the data, a reflection based on the literature and the legislation was carried out, which was the basis for planning and organizing the workshops and, subsequently, for formulating the syntheses that expressed the results of the research, validated by the participants. The interpretation phase is the moment to formulate "new concepts, definitions and interrelationships, representing the conclusions of the study"(9). This process "consists in the possibility of giving meaning to the findings or discoveries and contextualizing them in similar situations, that is, it is the socialization of the results"(9).

\section{Study scenario}

The research was developed in the second semester of 2016 and data was collected in September and October with 11 MHC counselors from a small city in the West Macro-region of Santa Catarina. Of the 11 participants, seven attended the six meetings (six users and one government provider), while the others participated in two or more meetings. The $\mathrm{MHC}$ has 12 full members and 12 alternate members, 50\% users and $50 \%$ service providers (non-governmental and governmental, respectively). All members of the Council were personally invited to participate in the investigation and the researcher explained the study in a regular $\mathrm{MHC}$ meeting. However, the effective participants were the 11 members who attended the first workshop, who, after clearing up all the doubts, signed an informed consent form, with a copy for each participant.

\section{Data source}

Data was collected through three strategies appropriate to each specific objective: 1) Documentary analysis of minutes and non-participant observation of $\mathrm{MHC}$ meetings in the second semester of 2016; 2) Recognition of the Council legislation (Ordinary Law, and Internal Regulation) and the legal management tools (Municipal Health Plan, Annual Planning and Management report); 3) Production workshops with the counselors.

\section{Data collection and organization}

In view of the first objective, the 17 meeting minutes from the period defined were analyzed, seeking to identify the participation dynamics of the counselors. The documentary analysis provides data evidence and specific details and allows making inferences ${ }^{(10)}$. This analysis gives stable, accurate, and broad information, containing names, references and details of the agenda and the discussions of the Board, enabling review if needed.

The non-participant observation complemented the documentary analysis. This type of observation determines that the observer acts as an attentive spectator, using an observation script based on the research objectives and recording occurrences of interest ${ }^{(11)}$. It consists of "thorough exam or attentive look at a phenomenon as a whole or at some of its parts"(11). Two MHC regular meetings were observed before the workshops and one after the third workshop. Data was recorded on a field journal, including data on the participation dynamics in the Council, the presence of the counselors, how the items of the agenda got to the meeting, the voting process and deliberations, among others.

The workshop, another strategy used, consists of a "meeting of people with common interests in order to study and work to acquire knowledge or deepen the study of a theme, under the guidance of a specialist"(12). Based on this concept, six workshops with two hours each were developed. They were carried out in a room provided by the Municipal Health Office and mediated by the student developing the research. On these occasions, the researcher received help from another student, who took the role of observer, taking notes of the non-verbal events during the discussions. Due to the time established by the academy and the period for the development of research, only 6 workshops were carried out.

The first three workshops used reading material (current legislation, Internal Regulation and MHC Ordinary Law) to promote reflection and discussion, considering the individual and collective experiences of being a counselor. In the three subsequent meetings, the workshops were aimed at identifying potentialities and weaknesses in the $\mathrm{MHC}$, as well as generating products. At this stage, the group decided to deepen the knowledge on the Ordinary Law of the Council and propose a new text, adapted to Resolution 453/2012 of the National Health Council (NHC). Each meeting was evaluated based on the dynamic "It's good that, what if, what a shame that", allowing criticisms and suggestions, which were annotated and transcribed by the assistant student, with the objective of organizing and planning subsequent meetings. From the second workshop, each meeting was started with the validation of data from the previous meeting, involving all participants, in order to obtain any addition or adjustments related to the theme.

\section{Data analysis}

The method for treatment of information used in this study was content analysis, based on thematic analysis. It is considered that "a thematic analysis consists of discovering the core meanings of a communication, the presence or frequency of which means something to the object of analysis"(13). In this sense, the analysis occurred in three stages: Pre-analysis, Categorization and Interpretation of data.

\section{RESULTS}

The profile of the study participants was characterized as follows: eight were users (three of them were alternate members) 
and three were government providers; $63.6 \%$ were female and $36.36 \%$ were male. Regarding the age of the participants, $63.6 \%$ were between 50 and 60 years old, $18.18 \%$ between 40 and 50 years old and $18.18 \%$ between 20 and 30 years old.

The analysis generated two thematic categories: 1) Social participation and the performance of social power in health management, which aimed to identify the forms of social participation that should be strengthened in the performance of social power; 2) Exchange and construction of knowledge, which was aimed at sharing and reflecting on individual experiences, anchoring them in the current legislation and building knowledge that could strengthen the performance of social power.

\section{Social participation and the performance of social power in health management}

During the development of the research, some counselors were distanced from the MHC. A documentary analysis indicated that the lack of a quorum was frequent. Of the 17 meetings held in the period analyzed, there was a minimum quorum in five (seven voting counselors), one meeting had eight counselors and 11 had no quorum. Thus, in only $29.4 \%$ of the MHC, a quorum for voting was present.

The workshops were important for understanding the absence of counselors in the meetings, and the participants expressed the need to mobilize and awaken, in other counselors, the interest in being part of this collegiate.

It's complicated, because we do not have enough participation. (User 1)

[...] at first it had much more participation. Now we're broken! [...] There was a lot of debate, [...] everyone had an idea. It was beautiful! (User 2)

It would be better if there were more people here. (Gov. Provider 2)

In relation to their knowledge and their attributions, the counselors report the imprecision of their function.

We're never up to date on health issues. We always participate, but it's always so fast! [...] We can't stop and ponder, study, to say yes or no. We are going [to the council], but we do not know what our exact function is. We should know the role of the counselor. Is that too much to ask? (User 5)

We go to the meetings just due to obligation. (User 3)

The data shows that counselors were unaware of what role they should play and felt a need to understand what it was. However, they pointed out the lack of mechanisms to broaden the debate during the meetings, highlighting the limited time available.

Still on their discourses, the participants recognized that the performance of social power goes beyond being present and signing the documents, which generated some discomfort in their actions as counselors. In this sense, it was noticed that most of them were unaware of the Ordinary Law and the Internal Regulation of the Council. Regarding the Municipal Health Plan (MHP), a management tool, they expressed vague memories of approval in the MHP after the explanation of the manager, but were not sure about its content. The counselors also expressed concern about the Management Reports (RAG) and their difficulty of interpretation.

Who knows the Council Regulation? (Researcher)

[Silence.]

Who knows the law of the Council? (Researcher)

[Silence. Negative signs with the head. ]

It's all there, in my office. If you want to see it, it's there. You can get it. (Gov. Provider 1)

Who built the Municipal Health Plan? (Researcher)

I did, along with the team. We looked at the old plan to know how to do it, because I did not know it either. [...] Do you remember? It was at that meeting, when $X$ came and presented the goals and everything, with the slides. Then you made some suggestions and it was changed at the time. Do you remember? That was the approval of the Plan. Everyone here was at that meeting. (Gov. Provider 1)

Another important aspect was the election of the members of the Council. For the participants, the institutions should choose people who want to participate in this collegiate and are available to attend the meetings.

The institutions should choose people available to participate. In some council, if the counselor does not come to three meetings, he's out!! (User 3)

That should be in the regulation. (Gov. Provider 1)

The person chosen must state if they accept to participate. Then, it depends on the level of commitment of each one, on their conscience. (User 5)

The presence of the counselors in the meetings of the MHC and in the workshops indicates the commitment of the participants with this deliberative body and with the research. However, the participants demonstrated lack of knowledge and of information that could guide their action in this collegiate body, whether favorable or not to the agenda presented in the Council.

The observation of the $\mathrm{MHC}$ meetings made it possible to perceive the empowerment of the board members and the transforming dynamics of their participation after the workshops. During the first observation, only few users were observed questioning what had been established. Attentive to the agenda, most of them passively accepted the manager's actions, such as holding the meeting even with the lack of a minimum quorum and not reading the minutes. At subsequent 
meetings, the counselors who participated in the research called for a quorum to deliberate on issues of the agenda, demanded the reading of the minutes, questioned management about the functioning of the health unit and the health team staff, demanded the participation of the other counselors in the meetings and invited people from society to participate in the discussions, increasing participation in the meeting.

\section{Exchange and construction of knowledge}

The first three workshops were aimed at assessing the participants' recognition of their roles and competences and their knowledge on the functioning, legislation and management tools of the Board, as well as their role in this group. In the first workshop, the participants were organized in two groups, respecting the balance of the categories represented in the Council. The activity was based on guiding questions: Group 1: what do I understand by Health Council and how does it work?; Group 2: where does the Health Council act? This moment promoted exchange of knowledge, discussion and reflection on the performance of the counselors, according to the group's reports.

The Council is about knowing how health works [...] monitoring, clarifying facts and approving resolutions. The health council consists of monthly meetings with representatives of society [institutions, government and health workers], voting of resolutions and possible benefits. (Group 1)

The health council works at the municipal level, with suggestions; it supervises the work of health professionals and all staff working in the area, assists in the work during campaigns, and works with the population, listening to complaints and even requests regarding schedules and things missing. (Group 2)

In this socialization, the answers were close to what is recommended in Resolution 453/2012, which shows concern regarding the supervision and approval of resolutions. When reflecting on the organization and its functioning, the participants demonstrated knowledge about representation and about their role in this collegiate. However, the documentary analysis and the observation showed that meetings during the period analyzed did not occur monthly and presented weaknesses in representation, especially regarding the professional category. The reports showed expanded knowledge on the practice of the health counselors, who brought suggestions and complaints from the community to the council, and followed the work of the multi-professional team.

The participants expressed concern about how the meetings occurred, the quorum and the legitimacy of collegiate deliberations. They considered that this situation could hinder municipal management, since often it would not be possible to provide the necessary referrals in a timely manner for the issues that require MHC approval.

If there is no quorum, there is no meeting, and if there is no meeting, I can not forward what needs approval. (Gov. Provider1)
At the start of the second workshop, the participants were asked about the knowledge of the current legislation. The unanimous response is represented by the user's speech below.

Yeah, but we did not know there was a law and a regulation. I've never seen it before! Now that we know, we need to read them more, change, improve, ask more. (User 5)

Subsequently, the group activity was started, following the same organization of the first workshop: Group 1 - reading Resolution 453/2012 and Ordinary Law 554/2010 of the MHC; Group 2 - reading Resolution 453/2012 and the MHC Internal Regulation. The activity consisted in identifying convergences and divergences between the current municipal legislation and the Resolution that guides the Health Councils and represented the first contact of the counselors with these documents. It was a unique moment of strengthening, empowerment, reflection on their practice and their responsibility, going from personal knowledge to a collective activity.

The proposal of the third workshop was to perceive the reality of the city and the knowledge about the Municipal Health Plan (MHP). In this sense, Resolution No. 453/2012, in its Fifth Guideline, item V, states that it is incumbent upon MHC to "establish guidelines for the elaboration of health plans and deliberate on their content according to the different epidemiological situations and the organizational capacity of the services"(4). However, the participants stated that they did not participate in the elaboration of the Municipal Health Plan (MHP), as well as the Internal Regulations and the Ordinary Law, and did not use it as an instrument for monitoring and evaluating health actions and services.

This workshop was aimed at understanding the Municipal Health Plan, from its elaboration to the monitoring of actions. For this, the need to know the reality of the city was initially considered. The participants were invited to collectively represent/draw, in brown paper, this reality, identifying relevant situations for health and possibilities to be contemplated in the Municipal Health Plan. Based on the drawings produced, the counselors pointed out fragilities and health problems, as well as potentialities and possibilities. In the workshop, the counselors identified the local reality with the possibility of drawing an epidemiological profile of the city and proposing actions for improvement. The importance of exchanging knowledge and awakening to a new form to act was identified and represented in the speech bellow.

\begin{abstract}
You know, no one has ever explained it to us, what a plan was, that it had to have these things... Because you can see how much good things we thought about here. But now that we know we can help, because we live here... and not only that... We have to get [the Plan] and look at it again later. (User 5)
\end{abstract}

The three subsequent workshops proposed the construction of a product as the result of the reflexive process, identified as a priority for the qualification of the MHC. At that moment, the dynamic called "The tree of the Health Council" was used. Like any tree, it also had roots that absorb nutrients 
necessary for survival. Thus, in order for the Council to remain nourished and fixed to earth, its roots must be structured by the SUS legislation (Resolution 453/2012, MHC Ordinance and Regiment, Municipal Health Plan, among others). In addition, the trunk is responsible for the support of the tree, for bringing the sap to the leaves and, in the reverse way, for bringing the food produced by the leaves in the photosynthesis. In this logic, the trunk consisted of the meetings, with agenda, participation of the counselors (minimum quorum), discussions, deliberations, and open to the participation of the population. The branches represent the counselors, who are the mediators between institutions and population in Council decisions. The leaves, responsible for photosynthesis, absorb carbon dioxide from the air and solar energy and return the necessary oxygen. Therefore, the Council needs to have, on the leaves, instruments and partnerships able to absorb the needs of the city and return proposals and actions to attend to these needs. These partners, in the perspective of cooperation between sector, include other municipal councils, articulated with municipal offices, municipal management, municipal institutions and the population itself.

\section{Collective construction - the product}

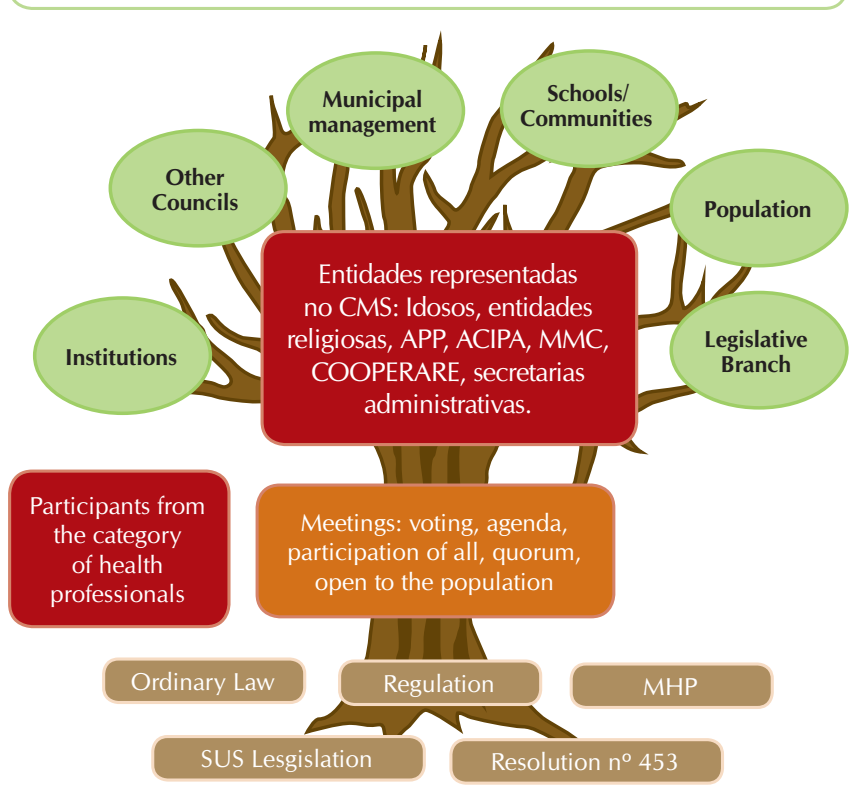

Source: Illustration of the tree built by the researcher and participants during the $4^{\text {th }}$ workshop of the Convergent Care Research.

Note: MHC - Municipal Health Council; PTA - Parent-Teacher Association; ACI$P A$ - Association of Commerce and Industry of Planalto Alegre; MMC - Peasant Women's Movement; COOPERARE - Family Farming Cooperative; MHP - Municipal Health Plan; SUS - Unified Health System.

Figure 1 - Tree of the Municipal Health Council

The tree analogy (Figure 1) was built with the participants present during the fourth meeting.

The data generated in the meetings was validated during the workshops, with the records of the discussions and contents learned brought into the meetings. At the end, it was considered that the MHC tree suffered many internal and external interferences, positive and negative, and that the "heart/center of it all" would be to modify the Ordinary Law and the Internal Regulation of the $\mathrm{MHC}$, adapting them to the legislation to better guide the counselor's actions. This way, the two subsequent workshops aimed to (re)organize the legislation. In the last meeting, the new document "MHC Ordinary Law" was approved by the participants. At the end of the CCR workshops, it was agreed that the new "Ordinary Law" document would be submitted for approval at a MHC meeting and that later, they would initiate the revision and updating of the Internal Regulation.

\section{DISCUSSION}

The absence of counselors at meetings and activities of the $\mathrm{MHC}$ encourages reflection on the legitimacy of the deliberations, as they would not be in accordance with the criteria of the legal systems (MHC Ordinary Law, MHC Internal Regulation and Resolution 453/2012 of CNS). However, it also raises questions about the commitment to participate and the effectiveness of the representation of the counselors. What does this absence mean? Is it due to lack of invitation, insufficient disclosure, difficulty access for the counselors, times of the meeting, the communication process at meetings, which has technical terms difficult to understand, or even due to lack of knowledge about the role and importance of the MHC?

The demonstration in favor of a greater presence in the meetings seemed to emphasize the importance of this instance as a space for dialogue, welcoming the external look of the community into the management of public policies in the area of health. These considerations are consistent with Law No. 8,142/90 and Resolution 453/2012, which establish that Health Council meetings are open to society's participation, making it a space for the exercise of citizenship ${ }^{(3-4)}$. In addition, society's participation can bring new points of view to the discussions, as indicated in the speeches, that is, the council stops seeing its image reflected in the mirror and comes to know new realities.

Participation related to social power can be understood as sharing of political power between State and society, as a dialogue between these actors in the decision-making process for public policies ${ }^{(2)}$. The analysis of the data revealed two forms of social participation that could be strengthened in the performance of social power: on the one hand, being an absentee counselor in the decisions of the Health Council; and on the other hand, being an advisor committed and interested in participating and being part of the council. These results refer to other researches that evaluated the organization and performance of Health Councils. In these studies, motivations and situations that lead to low participation in MHC meetings and decisions may involve: voluntary, unpaid and unprofessional work; lack of information and knowledge about the role of the Health Council and of the counselor; the power relations existing in these spaces, especially regarding political and management influences; the lack of popular organization in the representative institutions; lack of interest and self-accountability; besides the feeling of not belonging to that space ${ }^{(14-19)}$. 
The power relations existing in collegiate associations are usually quite strong and often put the users in disadvantage due to their lack of knowledge about the topics presented for discussion in the Council, and about their role as counselors $^{(15,19)}$. The health counselor represents social strength and the diversity of the community, and should bring community values, thoughts and demands to the deliberative space ${ }^{(19)}$. Therefore, recognition of what it means to be a counselor is indispensable.

Access to information is essential for the participation of counselors, especially in decision-making processes, which imply the possibility for the Councils to deliberate on health policies and to intervene in their realities ${ }^{(16)}$. In this sense, providing access to information and permanent education spaces is the best way to qualify the performance of social power and contribute to the action of the social subject in the fulfillment of the right to health. Thus, qualification is identified as important for empowerment and it is perceived as a dynamic process with an increase in "power and in personal and collective autonomy of individuals and social groups in interpersonal and institutional relations"(18).

Still in this perspective, the fifth guideline, competence I of Resolution 453/2012, says that it is incumbent upon the council "to strengthen social participation in the SUS and to mobilize and articulate society in a permanent way in defense of the constitutional principles of the SUS"(4).

This study also revealed representation as a potentiality related to social participation that can be strengthened for the performance of social power. The fact that the counselor represents an entity, a collective, not an individual person, requires, on the one hand, effective communication between entity and counselor and, on the other hand, "political organizations with capacity for vocalization and potential to generate spaces of power"(20).

Based on the reflective process on the performance of social power, the counselors began to recognize the council as a place of participation, and the methodology used gave them instruments to exercise citizenship in their participation. It is important to emphasize that empowerment processes take place in "conflicting arenas, where power relations are always expressed, but must be regarded not as watertight, determined, but as plastic, flexible, and therefore modifiable by human action-reflection-action"(18).

An active participation is related to the capacity of mobilization of the subjects, implying in their empowerment, which is essential for the effective performance of social power. The forms, means and tools used to promote this empowerment can be many, but access to information is essential to make the gears work.

During the CCR meetings, it was possible to perceive the relationship between dialogue and production of knowledge based on the knowledge and experiences that each participant brought. In order to perform social power, counselors must be aware of the importance and responsibility of their role in society and should be guided by ethics and citizenship, considering the political, social and economic scenario, in order to obtain results that respect social interests and justice ${ }^{(21)}$.
The critical-reflexive process started in the first workshop evidenced the need to increase knowledge about being a counselor, especially considering the legislation (Resolution 453/2012, Ordinary law of the council and Internal Regulation) and the management tools (Municipal Health Plan) . The topics covered in the subsequent workshops enabled counselors to take control of their own affairs with awareness of their skills and competences. In this sense, within the personal dimension, empowerment is achieved when people make use of democratic participation skills and political decision-making power ${ }^{(20)}$.

The workshops promoted exchanges and dialogue. The participants brought to the collective space new elements based on their own experiences, knowledge, weaknesses and potentialities of acting as a health counselor. For Freire, dialogue is essential for liberation, with "action and reflection, in such radical interaction that if one is sacrificed - even in part - the other immediately suffers"(20).

This process of "action-reflection-action" was noticed in the changes in the actions of the counselors in the workshops and in the meetings of the Council. The involvement of the counselors in the process of re-elaboration of the Ordinary Law encouraged a broad reflection on the importance of the Council, its structure, its functions and its responsibilities. It also expanded the understanding about the co-responsibility of this collegiate body in the planning, execution and inspection of municipal public policies.

\section{Study limitations}

The limitations of this study are the non-participation of all municipal health counselors who were full members and the low participation of government representatives and health professionals (totaling only one participant who was a government representative). These factors made it impossible to identify the reasons for not participating both in the study and in the activities of the Health Council.

In addition, due to the limited time of the academy, the data collection was performed in a period of three months, which is considered a limitation for a more robust analysis of the methodology used (CCR).

\section{Contributions to the area of nursing, health or public policy}

Considering the training of the nursing professional, the research provided a closer approximation to one of its competences: to promote the mobilization and participation of the community, seeking an effective social power as advocated in the National Primary Care Policy, an issue not addressed during formal training.

\section{FINAL CONSIDERATIONS}

The present study, encouraged by the need to deepen the experiences and knowledge about the performance of social power, made it possible to identify the participation dynamics of a municipal health council, to develop a critical-reflexive process about "being a counselor" with municipal counselors, to identify weaknesses and possibilities of this collegiate, and to collectively generate new knowledge and re-elaborate the 
Ordinary Law of the $\mathrm{MHC}$, in accordance with the current legislation.

Regarding the participation dynamics, there is a need to increase participation, considering the presence of the counselors in the meetings, the representation and the interaction in the discussions and deliberations of the items in the agenda. Possibilities for increasing participation could include convening, dialogue with institutions, creation of permanent information channels, and the continuing need to increase awareness of the importance of the Council. These possibilities were partially promoted by this research. Future studies should investigate the reasons for non-participation, considering that this reality is not exclusive to the investigated council, according to other studies on the subject.

In this sense, a commitment with local reality is part of the university's social and scientific role Moreover, as a generator of knowledge, the university should also strengthen the empowering process of the actors in their different spaces. It is fundamental to promote studies such as this one and to enhance partnerships that allow a continuous permanent education for health counselors, with the objective of qualifying the performance of social power/participation in public management spaces.

Regarding the critical-reflexive process, the method used in this study, the Convergent Care Research (CCR), combined different strategies that made it possible to identify, through workshops, the reality of the Council and of the counselors. In addition, it enabled dialogue, interaction and reflection on the needs, weaknesses and potentialities of the Council and of the counselors, respecting their individualities in the construction of collective knowledge. The use of CCR is recommended for future research, since it allows for immediate changes in reality. The appropriation of this methodology was represented in this study by the update suggested for the Ordinary Law, which was the result of the research process and brought experiences of empowerment for the subjects and for the collective.

For the researcher, the research method used was challenging, since it presents specificities for its development, mainly in relation to the moments of approximation with practice, detachment, reflection on the data and on the theoretical framework, and the convergence of these data with practice again, which represent the stage of interpretation and guarantees the scientific rigor of the study. For the researcher, it is essential to respect this process and to be clear about the need to create a link with the object of study, without getting involved in a way that could bias the results. In this modality, the main function of the research is to result in improvements for the space and for the subjects, involving their participation in the collective construction of these improvements.

Finally, the qualification for the performance of social power also qualifies the construction of public policies consistent with the reality of the city and with the principles and guidelines of SUS.

\section{REFERENCES}

1. Paim JS. A Reforma Sanitária e o CEBES. Projeto Formação em cidadania para saúde: temas fundamentais da reforma sanitária. Rio de Janeiro: CEBES; 2012.

2. Bava MCG, Rocha JSY. A participação e seu papel na construção da saúde. In: Rocha JSY (Org.). Manual de Saúde Pública e Saúde Coletiva no Brasil. São Paulo: Atheneu, 2012. p. 191-199.

3. Brasil. Ministério da Saúde. Lei 8.142, 28 de dezembro de 1990. Dispõe sobre a participação da comunidade na gestão do SUS e sobre as transferências intergovernamentais de recursos financeiros na área de saúde e dá outras providências [Internet]. Brasília: MS; 1990[cited 2016 Nov 23]. Available from: conselho.saude.gov.br/web_siacs/docs/l8142.pdf

4. Brasil. Ministério da Saúde. Resolução no 453, de 10 de maio de 2012. Dispõe sobre diretrizes para instituição, reformulação, reestruturação e funcionamento dos Conselhos de Saúde [Internet]. Brasília: MS; 2012[cited 2016 Nov 23]. Available from: http://conselho.saude.gov.br/ultimas_noticias/2012/12_jun_resolucao453.html

5. Planalto Alegre. Lei no 33 de 15 de setembro de 1993. Dispõe sobre a criação do Conselho Municipal de Saúde e dá outras providências [Internet]. Planalto Alegre: 1993. Available from: http://www.legislacaomunicipal.com/busca_leis.php?municipio=95990255000155

6. Martins ALX, Santos SMR. O exercício do controle social no Sistema Único de Saúde: a ótica do enfermeiro como membro do Conselho Local de Saúde. Saúde Soc [Internet]. 2012[cited 2016 Nov 18];21(1):199-209. Available from: www.scielo.br/pdf/ sausoc/v21s1/17.pdf

7. Reibnitz KS, Prado ML, Lima MM, Kloh D. Convergent-care research: bibliometric study of dissertations and theses. Texto Contexto Enferm [Internet]. 2012[cited 2016 Dec 12];21(3):702-7. Available from: http://www.scielo.br/pdf/tce/v21n3/en_v21n3a27.pdf

8. Trentini M, Paim L. Pesquisa convergente-assistencial: um desenho que une o fazer e o pensar na prática assistencial em saúdeenfermagem. 2 ed. Florianópolis: Insular; 2004.

9. Rocha PK, Prado ML, Silva DMGV. Pesquisa Convergente Assistencial: uso na elaboração de modelos de cuidado de enfermagem. Rev Bras Enferm [Internet]. 2012 [cited 2016 Dec 12];65(6):1019-25. Available from: www.scielo.br/pdf/reben/v65n6/a19v65n6.pdf

10. Yin RK. Estudo de caso: planejamento e métodos. 3 ed. Porto Alegre: Bookman; 2005.

11. Richardson RJ. Pesquisa social: métodos e técnicas. 3 ed. São Paulo: Atlas; 2007.

12. Anastasiou LGC, Alves LP. Processos de ensinagem na universidade: pressupostos para as estratégias de trabalho em aula. 5 ed. Joinvile: UNIVILLE; 2005. 
13. Minayo MCS. O Desafio do Conhecimento: pesquisa qualitativa em saúde. 10 ed. São Paulo: HUCITEC; 2007.

14. Kleba ME, Comerlatto D, Colliselli L. Promoção do empoderamento com conselhos gestores de um pólo de educação permanente em saúde. Texto Contexto Enferm [Internet]. 2007[cited 2016 Nov 12];16(2):335-42. Available from: www.scielo.br/pdf/tce/ v16n2/a18v16n2.pdf

15. Cotta RMM, Cazal MM, Martins PC. Conselho Municipal de Saúde: (re)pensando a lacuna entre o formato institucional e o espaço de participação social. Ciênc Saúde Colet[Internet]. 2010[cited 2016 Dec 02];15(5):2437-45. Available from: http://www.scielo. $\mathrm{br} / \mathrm{pdf} / \mathrm{csc} / \mathrm{v} 15 \mathrm{n} 5 / \mathrm{v} 15 \mathrm{n} 5 \mathrm{a} 18 . \mathrm{pdf}$

16. Cotta RMM, Cazal MM, Rodrigues JFC. Participação, Controle Social e Exercício da Cidadania: a (des)informação como obstáculo à atuação dos conselheiros de saúde. Physis[Internet]. 2009[cited 2016 Dec 12];19(2):419-438. Available from: http://www. scielo.br/pdf/physis/v19n2/v19n2a10.pdf

17. Comerlatto D, Colliselli L. A dinâmica participativa e as reuniões em conselhos municipais: revelando processos e desafios. In: Wendhausen ALP, Kleba ME (Orgs.). Conselhos gestores e empoderamento: vivências e potenciais da participação social na gestão pública. Jundiaí: Paco Editorial; 2012. p. 119-42.

18. Kleba ME, Wendhausen ALP. Empoderamento e participação social na gestão pública. In: Wendhausen ALP, Kleba ME (Orgs.). Conselhos gestores e empoderamento: vivências e potenciais da participação social na gestão pública. Jundiaí: Paco Editorial; 2012. p. 41-59.

19. Zambon VD, Ogata MN. Controle social do Sistema Único de Saúde: o que pensam os conselheiros municipais de saúde. Rev Bras Enferm [Internet]. 2013[cited 2016 Dec 12];66(6):921-7. Available from: www.scielo.br/pdf/reben/v66n6/17.pdf

20. Freire P. Pedagogia do Oprimido. 17 ed. V 21. Rio de Janeiro: Paz e Terra; Simões ML, Santos JP (Revs.). 1987.

21. Rocha EM, Cunha JXP, Lira LSSP, Oliveira LB, Nery AA, ABA Vilela, et al. O papel do conselheiro municipal de saúde na fiscalização do orçamento público. Saúde Debate [Internet]. 2013[cited 2016 Dec 01];37(96):104-11. Available from: www. scielo.br/pdf/sdeb/v37n96/12.pdf 